\begin{tabular}{c} 
Volume and Issues Obtainable at Center for Sustainability Research and Consultancy \\
Journal of Accounting and Finance in Emerging Economies \\
ISSN: 2519-0318 ISSN (E) 2518-8488 \\
Volume 6 Issue 3 September 2020 \\
JSRᄃ \\
Journal homepage: $\underline{\text { www.publishing.globalcsrc.org/jafee }}$ \\
\hline
\end{tabular}

\title{
Firm Life Cycle and Financial Performance: Evidence from Nigeria
}

\author{
${ }^{1}$ Onipe Adabenege Yahaya, ${ }^{2}$ Joseph Majiyebo Onyabe \\ ${ }^{1}$ Department of Accounting, Faculty of Management Sciences, Nigerian Defense Academy, Kaduna, \\ Nigeria, yoadabenege@nda.edu.ng \\ ${ }^{2}$ Human Resource Management, Group, Finance and Corporate Services, Directorate, Federal Mortgage \\ Bank of Nigeria, Abuja, Nigeria, jmonyabe@gmail.com
}

\begin{tabular}{l}
\hline ARTICLE DETAILS \\
\hline History \\
Revised format: August 2020 \\
Available Online: September \\
2020 \\
\hline
\end{tabular}

Keywords

Decline, growth, introduction, maturity, shake-out.

\section{JEL Classification}

M41, M48

\begin{abstract}
Purpose: There are limited scholarly works in Nigeria which examine the influence of firm life cycle on financial performance. This study has filled this gap by examining the effects of firm life cycle on financial performance of listed firms in Nigeria.

Design/Methodology/Approach: Correlational research design was used and data were extracted 91 listed firms over a ten-year period (2010-2019) and analyzed using descriptive statistics (mean, standard deviation, minimum mean and maximum mean) and inferential statistics (correlation coefficients and multiple regression analysis). Diagnostic checks such as normality, multicollinearity, heteroskedasticity, serial (auto) correlation and panel effects tests were carried out and the results were used to decide the appropriate methods of regression analysis.
\end{abstract}

Findings: We find maturity stage to have positive and significant effect on financial performance. However, we fail to find any significant effect at introductory, growth and shake-out stage.

Implications/Originality/Value: The study, therefore, concludes that the maturity phase is the most critical stage and recommends that managers should pay greater attention to their businesses, particularly during the period of maturity to avoid shakeout or decline.

(C) 2020 Center for Sustainability Research and Consultancy Pakistan under a Creative Commons Attribution-NonCommercial-ShareAlike

4.0

Corresponding author's email address: yoadabenege@ nda.edu.ng

Recommended citation: Yahaya, O. A., and Onyabe, J, M. (2020). Firm life cycle and financial performance: Evidence from Nigeria. Journal of Accounting and Finance in Emerging Economies, 6(3), 723-732

\section{Introduction}

A leading body of study has suggested that firms undergo life-cycle stages and that these stages are characterized by marked differences in financial performance (Inyiama \& Nwankwo, 2016). The evidence suggests that changes in firm life cycle have notable influence on financial performance. However, little is 
known about the association with a firm's financial performance at different stages of firm life cycle. This is particularly true in Nigeria where very little or no interest is shown by scholars in this regard.

In this study, we examine whether differences in firm life cycle affect financial performance. We focus on the introductory stage (start), growing stage, old age stage, decline stage and shakeout stage (restructure). We also focus on three proxies of financial performance (return on capital employed, internal rate of return and economic value added). Firm financial performance is critical to the health of any economy because government alone cannot provide the much needed employment for its citizens. Also, government derives revenue from taxes levied on corporations (e.g., corporate income tax, capital gains tax and education tax).

A healthy firm financial performance is also critical to communities because it is only then that firms would be in position to provide social amenities through corporate social responsibilities; such may include but not limited to donations, training and development, community development and building of town halls, roads, schools, elderly homes, social gardens, health, safety and environmental facilities.

While there are few prior literature that examined the link between firm life cycle and financial performance (Ashbaugh-Skaife et al., 2009; Ogneva et al., 2007), this study is one of the few attempts to interrogate the effects of firm life cycle on financial performance in Nigeria. consequently, the following hypotheses were developed and tested:

$\mathrm{HO}_{1}$ : Business introductory stage has no significant effect on financial performance of listed firms in Nigeria.

$\mathrm{HO}_{2}$ : Business growth stage has no significant effect on financial performance of listed firms in Nigeria.

$\mathrm{HO}_{3}$ : Business maturity stage has no significant effect on financial performance of listed firms in Nigeria.

$\mathrm{HO}_{4}$ : Business decline stage has no significant effect on financial performance of listed firms in Nigeria.

$\mathrm{HO}_{5}$ : Business shakeout stage has no significant effect on financial performance of listed firms in Nigeria.

The paper is significant in many respects. Stakeholders (managers, employees, creditors, governments, regulators, tax authorities, researchers, corporate promoters, angelic funds providers, business starters, entrepreneurs and dreamers) may gain from the findings of the study. Also, the study contributes to our understanding of concepts, empirics, theories, models and methods. Furthermore, the paper provides information for policy and performance improvements, more research and new body of knowledge. The remaining parts of the study are organized into literature review, methodology, results, conclusions and recommendations. Section two describes prior literature in terms of key concepts, empirics and theories. Section three introduces models and methodology and section four discusses the results and section five concludes and offers recommendations.

\section{Literature Review}

The goal of the firm is the maximization of shareholders' wealth. This is achieved through strategies that enhance financial performance by increasing revenue and at the same reducing costs associated with generating such revenue. Thus, financial performance is an important phenomenon within the realm of corporate existence. While, it is true that the primary goal of the firm is to create customers, it is unimaginable that the firm will be able on sustainable basis deliver on this goal without sustainable delightful performance. 
Financial performance measures the ability and capacity of the firm to add value to inputs and produce outputs that are measurable in monetary terms. It measures how well a firm is able to convert resources into wealth. A good financial performance is highly desirable among stakeholders. Government at all levels need firms to perform financially well in order to help create jobs and wealth with attendant multiplier effects on the economy in terms of taxes, salaries, wages and pension payments. Firms are the macro unit of the economy, so a healthy firm contributes to a healthy economy.

Financial performance is often discussed in the context of several concepts such as return on capital employed (ROCE), internal rate of return (IRR), economic value added (EVA), return on assets (ROA), return on equity (ROE), return on investment (ROI), return on sales (ROS), earnings per share (EPS), dividend per share (DPS), share price (SP) and market value expressed as a percentage of book value of equity (Tobin'sQ). However, in this study, three concepts of firm financial performance were discussed, namely: ROCE, IRR and EVA. ROCE indicates the capacity of the firm to turn investment assets regardless of the supplier and the conditions attached to it to generate income. It is measured as profit before interest and taxes divided by capital employed.

IRR is a measure of return internal to each investment asset. This suggests that different investment assets have different rate of return given the specifics of each investment asset. One of the advantages of using the IRR is that it accounts for time in value of money by taking into consideration the rate of inflation in the economy. However, it fails to discriminate in terms of the size of the investment assets. It simply compares cash flows to the amount of initial investment assets without looking at the investment assets size. EVA is actually the excess value created from economic engagement. It is in a sense the excess value created over and above the internal rate of return or expected rate of return. It is the excess left after removing the cost of capital from profit made, after adjusting for taxes.

Firm financial performance is influenced by several factors. However, this study considers the effects of firm life cycle on financial performance. It is true that firms generally faced stiff competition among themselves in maximizing shareholders' wealth. This is done yet undergoing changes in life cycle. A typical firm life cycle starts with introductory phase, growth phase, maturity phase and end with decline phase or shakeout (revival) phase.

Few empirical studies have examined the nexus between firm life cycle and firm financial performance. For example, Wahba and Elsayed (2014) examine both the theoretical and empirical evidence regarding the impact of firm life cycle on financial performance using econometric analysis of a sample of 84 Egyptian listed firms over the period 2005 to 2010. The result provided strong evidence and demonstrated that financial performance is negative in the inception stage; it has exerted a positive and significant coefficient on financial performance for those firms that are in the expansion stage, the maturity stage or the revival stage. Hossain (2014) examines the influence of firm life cycle on profitability of Australian firms (1990-2012). The study shows that the return on capital employed declines as the firm life cycle increases.

Gunu and Adamade (2015) empirically examine the association between corporate life cycle and financial performance. They use a pooled and disaggregated dataset for manufacturing companies in Nigeria. An inverse relationship was found existing between firm introductory stage and financial performance. Also, Oluwatayo et al. (2016) examine the influence of organisation's life cycle on performance of architectural firms in Nigeria. The findings indicate that at maturity, organisation's performance varies. 
Zhou et al. (2016) interrogate the influence of firm life cycle on financial performance in China and find that performance varies with different stages. Habib and Hassan (2017) investigate the financial performance consequences of firms at different stages of firm life cycle. They find that financial performance is higher in the introduction and decline stages of the life cycle, but lower in the growth and mature stages. They also find that during introduction and decline stage (growth and maturity stage) affect future performance positively.

Gulec and Karacaer (2017) analyze the firm life cycle and financial performance indicators. They develop five hypotheses that are related to firm size, profitability, stock returns, liquidity and risk of the firms for three different stages through using descriptive statistics and test. Results show that matured firms are more profitable and get higher stock returns. Costa, et al. (2017) analyse the relation between firms' life cycles stages and financial ratios. They applied multinomial logistic regression analysis on a sample of 1,515 observations of public companies listed on BM\&FBOVESPA between 2005 and 2012. The results show that return on equity is higher at growth and maturity stages.

Bayat and Noshahr (2018) examine the effect of firm life cycle on corporate performance, where firm growth was used as the independent variable and return on investment and capital expenditures as the dependent variable. The population was the firms listed in the Tehran Stock Exchange using systematic elimination sampling method, 130 firms were selected as the sample with study period of 2012-2016. Data collection method was library with multiple regressions, and panel data was used to test the hypotheses. The results indicated that firm growth of has a positive and significant effect on return on investment and capital expenditures. Khamak et al. (2018) examine the relationship between the stages of firm life cycle and performance using data extracted from the annual reports and accounts of 118 listed firms on the Tehran Stock Exchange over a period of seven years. The results indicate that there is positive association among start, growth and maturity phases and financial performance.

Chang and Ma (2019) investigate how different firm life stages influence firm performance and maturity stage to influence financial performance. Shahzad et al. (2019) examine the current and future performance of firms across the different firm life cycle stages. They find financial performance to be higher during the introduction and decline stages and lower during the mature and growth stages. Yoo et al. (2019) interrogate the influence firm life cycle has on performance and find significant effects. The next section describes the methodology of the study.

\section{Methodology}

This study uses correlational research design. The sample consists of 91 listed firms on the Nigerian Stock Exchange. The data were collected from the annual reports and accounts of the firms and analysed using both descriptive (mean, standard deviation, minimum mean and maximum mean) and inferential statistics (Pearson product moment correlation and multiple regression). Diagnostic checks and post estimation tests such as multicollinearity, normality, heteroskedasticity, serial (auto) correlation, stationarity and panel effect were carried out in order to ensure that appropriate regression models are applied. The following models were used:

$$
\begin{aligned}
& \operatorname{ROCE}_{i, t}=\alpha+\beta_{1} I N T_{i, t}+\beta_{2} G R W_{i, t}+\beta_{3} M A T_{i, t}+\beta_{4} S H K_{i, t}+\beta_{5} D E C_{i, t}+\varepsilon_{i, t} \ldots \ldots \ldots \ldots \ldots \text { (1) } \\
& I R R_{i, t}=\alpha+\beta_{1} I N T_{i, t}+\beta_{2} G R W_{i, t}+\beta_{3} M A T_{i, t}+\beta_{4} S H K_{i, t}+\beta_{5} D E C_{i, t}+\varepsilon_{i, t} \ldots \ldots \ldots \ldots \ldots \ldots \text { (2) } \\
& E V A_{i, t}=\alpha+\beta_{1} I N T_{i, t}+\beta_{2} G R W_{i, t}+\beta_{3} M A T_{i, t}+\beta_{4} S H K_{i, t}+\beta_{5} D E C_{i, t}+\varepsilon_{i, t} \ldots \ldots \ldots \ldots \ldots \ldots \text { (3) }
\end{aligned}
$$

Whereas:

ROCE $=$ Return on capital employed, measured as earnings before interest and taxes divided by capital employed, which is total assets-current liabilities (Etale \& Otuya, 2018; Madugba \& Ogbonnaya, 2016). 
$\mathrm{IRR}=$ Internal rate of return is the discount rate that makes the net present value of a project zero (Patrick \& French, 2016; Magni, 2010).

EVA $=$ Economic value added, measured as Net operating profit after taxes - [Invested Capital (Debt + capital leases + shareholders' equity) multiplied by Weighted average cost of capital] as used by Andrija and Filip (2017).

$\alpha=$ Alpha (Constant)

$\beta_{1}-\beta_{5}=$ Beta coefficients to be estimated

INT = Introductory stage as measured by Zhou et al. (2016)

GRW = Growth stage as measured by Zhou et al. (2016)

MAT = Maturity stage as measured by Zhou et al. (2016)

SHK = Shake out stage as measured by Zhou et al. (2016)

DEC $=$ Decline stage as measured by Zhou et al. (2016)

$\mathrm{i}=$ Firm script (in this case, $\mathrm{i}=91$ firms)

$\mathrm{t}=$ Time script (in this case, $\mathrm{t}=10$ years)

$\varepsilon=$ Idiosyncratic error term

It is useful to note that three control variables (firm size, firm age and financial leverage) were initially introduced into the three models in order to control financial performance so that the true effects of firm life cycle on financial performance can be correctly estimated. However, they were found not to be significant and therefore eliminated completely from the models.

\section{Data Analysis and Interpretation}

Section 4 displays and deliberates the findings of analyses conducted in the study (descriptive analysis, diagnostic checks and post estimation tests and inferential statistical analysis).

\section{Table 1}

\section{Results of Descriptive Analysis}

\begin{tabular}{lccccc}
\hline $\begin{array}{l}\text { Variables of } \\
\text { Interest }\end{array}$ & $\begin{array}{c}\text { No. of } \\
\text { Observation }\end{array}$ & Mean & $\begin{array}{c}\text { Standard } \\
\text { Deviation }\end{array}$ & Minimum Mean & $\begin{array}{c}\text { Maximum } \\
\text { Mean }\end{array}$ \\
\hline ROCE & 910 & .179 & .784 & -13.700 & 3.293 \\
IRR & 910 & .105 & .0318 & .046 & .143 \\
EVA & 910 & .0767 & .786 & -13.843 & 3.175 \\
INT & 910 & .001 & .003 & 0 & 1 \\
GRW & 910 & .0025 & .004 & 0 & 1 \\
MAT & 910 & .005 & .005 & 0 & 1 \\
SHK & 910 & .002 & .004 & 0 & 1 \\
DEC & 910 & .0003 & .002 & 0 & 1 \\
\hline
\end{tabular}

Source: Authors' Computations using STATA 13

As clearly shown in Table 1, the number of observations is 910 made up of 91 listed firms multiplied by the 10 year-period covered by the study. The mean statistic value of return on capital employed is 0.179 , which means that for every one naira capital employed, the firms on the average generated 17.9 per cent. In the same context, the internal rate of return is 0.105 , meaning that for every one invested, the projectspecific IRR is $10.5 \%$. Also, Table 1 shows that the economic value added is 0.0767 , which means that for every one naira invested, the wealth addition is 7.67 per cent. Furthermore, the introductory stage shows mean value of 0.001, growth stage: 0.0025, maturity stage: 0.005 , shakeout stage: 0.002 and decline stage is 0.0003 .

Table 2 tests for the presence or absence of multicollinearity in the independent variables. The results shows that firm introductory stage is significantly negatively correlated with return on capital employed and economic value added. However, it has insignificantly negative association. Also, growth stage shows 
insignificant negative association with ROCE and EVA, while showing significant positive association with IRR. In addition, maturity stage shows significant positive effects on ROCE and EVA but insignificant positive association with IRR. In the same line, shakeout stage shows insignificant positive effects on ROCE and EVA but significant negative effect. Decline stage shows insignificant negative effects on ROCE, IRR and EVA.

Table 2

Results of Association Matrix

\begin{tabular}{lrrrrrrrr}
\hline & ROCE & IRR & EVA & INT & GRW & MAT & SHK & DEC \\
\hline ROCE & 1.000 & & & & & & & \\
IRR & -0.037 & 1.000 & & & & & \\
& 0.438 & & & & & & \\
EVA & 0.999 & -0.08 & 1.000 & & & & \\
& 0.000 & 0.105 & & & & & \\
INT & -0.182 & -0.001 & -0.18 & 1.000 & & & \\
& 0.0001 & 0.9923 & 0.0001 & & & & \\
GRW & -0.02 & 0.08 & -0.023 & -0.12 & 1.000 & & & \\
& 0.679 & 0.093 & 0.631 & 0.011 & & & & \\
MAT & 0.111 & 0.020 & 0.109 & -0.31 & -0.47 & 1.000 & & \\
& 0.020 & 0.674 & 0.021 & 0.000 & 0.000 & & & \\
SHK & 0.010 & -0.079 & 0.014 & -0.14 & -0.21 & -0.544 & 1.000 & \\
& 0.828 & 0.096 & 0.776 & 0.003 & 0.000 & 0.000 & & \\
DEC & -0.029 & -0.042 & -0.027 & -0.05 & -0.07 & -0.190 & -0.08 & 1.000 \\
& 0.548 & 0.381 & 0.573 & 0.300 & 0.120 & 0.0001 & 0.069 & \\
\hline SOUrCe: & A & & & & & \\
& & &
\end{tabular}

Source: Authors' Computations using STATA 13

As clearly shown in Table 2, three of the coefficients are greater than 0.70 (introductory stage and IRR is .9923; shakeout and ROCE is .828; shakeout and EVA is .776). These results indicate the presence of multicollinearity among the 5 independent variables. Table 3 confirms the results in Table 2 on the presence of multicollinearity.

As clearly shown in Table 3, DEC has been automatically eliminated from the independent variables because of the presence of multicollinearity. The VIF figures for maturity, shakeout, growth and introductory stage are now within acceptable bracket of less than 10 as suggested by Gujarati (2003). Therefore, the results in Table 3 indicate that the multicollinearity level is mild and tolerable. Table 4 presents the results of normality test using Shapiro Wilk test.

\section{Table 3}

Results of Multicollinearity Test

\begin{tabular}{lcc}
\hline Variables of Interest & $\begin{array}{c}\text { Variance Inflation } \\
\text { Factor }\end{array}$ & Tolerance Level \\
\hline MAT & 8.99 & 0.111 \\
SHK & 6.29 & 0.159 \\
GRW & 5.41 & 0.185 \\
INT & 3.27 & 0.306 \\
Mean VIF & 3.88 & \\
\hline
\end{tabular}

Source: Authors' Computations using STATA 13

Note: DEC is omitted because of collinearity

The results in Table 4 show the individual variable's normality test values. All the prob $>\mathrm{z}$ values with the exception of maturity are significant even at 1 per cent. These imply that the variables are not normally distributed. This requires the use of robust standard errors instead of the normal standard errors in the 
multiple regression analysis as shown in the results in Table 8. However, it is instructive to note that maturity is normally distributed since the Prob $>\mathrm{z}$ value is greater than .05 .

Table 4

Results of Normality Test

\begin{tabular}{lccccc}
\hline $\begin{array}{l}\text { Variables of } \\
\text { Interest }\end{array}$ & $\begin{array}{c}\text { No. of } \\
\text { Observation }\end{array}$ & $\mathrm{W}$ & $\mathrm{V}$ & $\mathrm{z}$ & Prob > z \\
\hline ROCE & 910 & 0.343 & 197.770 & 12.638 & 0.000 \\
IRR & 910 & 0.852 & 44.592 & 9.078 & 0.000 \\
EVA & 910 & 0.344 & 197.586 & 12.636 & 0.000 \\
INT & 910 & 0.947 & 16.117 & 6.646 & 0.000 \\
GRW & 910 & 0.978 & 6.596 & 4.510 & 0.000 \\
MAT & 910 & 0.999 & 0.052 & -7.047 & 1.000 \\
SHK & 910 & 0.986 & 4.364 & 3.522 & 0.0002 \\
\hline
\end{tabular}

Source: Authors' Computations using STATA 13

Table 5

Results of Serial (Auto) Correlation and Heteroskedasticity Tests

\begin{tabular}{llccc}
\hline & \multicolumn{2}{c}{$\begin{array}{c}\text { Wooldridge Test for Serial (Auto) } \\
\text { Correlation in Panel Data }\end{array}$} & \multicolumn{2}{c}{$\begin{array}{c}\text { Breusch-Pagan / Cook-Weisberg Test for } \\
\text { Heteroskedasticity }\end{array}$} \\
Model & $\mathrm{F}(1,90)$ & Prob $>\mathrm{F}$ & $\mathrm{Chi}^{2}(1)$ & Prob $>\mathrm{Chi}^{2}$ \\
\hline ROCE & 37.65 & 0.000 & 1112.07 & 0.000 \\
IRR & 3.96 & 0.111 & 1.86 & 0.173 \\
EVA & 113.21 & 0.000 & 1083.29 & 0.000 \\
\hline
\end{tabular}

Source: Authors' Computations using STATA 13

As clearly shown in Table 5, both ROCE and EVA models have Prob $>\mathrm{F}$ that is significant, meaning that the two models have serial (auto) correlation problem. This calls for the use of Newey regression analysis (Newey West standard errors). However, the results also show that the IRR model is free of serial (auto) correlation problem because p-value is greater than .05. Table 6 presents the results of unit root test, which tests for the presence or otherwise of stationarity in the variables of interest. Also, as shown in Table 5, the Prob>Chi ${ }^{2}$ for ROCE and EVA are both significant even at 1 per cent. These results clearly indicate the presence of heteroskedasticity in the two models. However, the Prob $>\mathrm{Chi}^{2}$ of the IRR model shows that the model is not significant. Table 6 presents the results of serial (auto) correlation analysis.

\section{Table 6}

\section{Unit-Root Test}

\begin{tabular}{lrr}
\hline Model & Statistic & p-value \\
\hline ROCE & 744.444 & 0.000 \\
IRR & 150.417 & 0.958 \\
EVA & 615.614 & 0.000 \\
INT & 44.936 & 1.000 \\
GRW & 73.408 & 1.000 \\
MAT & 137.562 & 0.994 \\
SHK & 66.794 & 1.000 \\
\hline
\end{tabular}

Source: Authors' Computations using STATA 13

As clearly shown in Table 6, ROCE and EVA models failed unit root test. However, IRR, INT, GRW, MAT and SHK all passed the stationarity test. 
Table 7

Results of Random Effects Test

\begin{tabular}{lcc}
\hline Model & $\mathrm{Chi}^{2}$ & ${\text { Prob }>\mathrm{Chi}^{2}}^{2}$ \\
\hline ROCE & 0.48 & 0.244 \\
IRR & 0.000 & 1.000 \\
EVA & 0.43 & 0.256 \\
\hline
\end{tabular}

Source: Authors' Computations using STATA 13

Table 7 shows that the p-values of the models are greater than .05 , leading to conclusion that the OLS (pooled model) is more appropriate than random or fixed effects. In other words, there are no firmspecific effects in the data.

\section{Table 8}

Results of OLS Regression

\begin{tabular}{|c|c|c|c|c|c|c|c|c|c|}
\hline \multirow{2}{*}{$\begin{array}{l}\text { Model } \\
\text { Variable }\end{array}$} & \multicolumn{3}{|c|}{ ROCE } & \multicolumn{3}{|c|}{ IRR } & \multicolumn{3}{|c|}{ EVA } \\
\hline & Coefficient & $\mathrm{t}$ & $P>t$ & Coefficient & $\mathrm{t}$ & $\mathrm{P}>\mathrm{t}$ & Coefficient & $\mathrm{t}$ & $P>t$ \\
\hline INT & -36.510 & -.80 & .424 & -37.371 & -.82 & .415 & .861 & .83 & .407 \\
\hline GRW & 10.057 & 1.43 & .155 & 8.649 & 1.19 & .238 & 1.408 & 1.51 & .133 \\
\hline MAT & 20.891 & 2.88 & .005 & 19.929 & 2.69 & .009 & .961 & 1.10 & .273 \\
\hline SHK & 15.472 & 1.48 & .143 & 15.062 & 1.41 & .162 & .410 & 0.44 & .659 \\
\hline _cons & -13.976 & -.38 & .707 & -26.203 & -.71 & .482 & 12.227 & 7.56 & .000 \\
\hline Obs & & 442 & & & 442 & & & 442 & \\
\hline $\mathrm{F}(7,434)$ & & 2.79 & & & 1.69 & & & 2.77 & \\
\hline Prob $>F$ & & .011 & & & .110 & & & .012 & \\
\hline $\mathrm{R}^{2}$ & & .039 & & & .026 & & & .037 & \\
\hline
\end{tabular}

Source: Authors' Computations using STATA 13

The results in Table 8 are as a consequence of the conclusion drawn from the results in Table 7, which show clearly that there are no panel effects in the three models and therefore there is no need to test for random effects or fixed effects using Hausman specification test. In order to avoid confusion in interpretation of the results, discussions of findings and testing of hypotheses, only one of the models is adopted, which is ROCE. The reasons are not farfetched; it has a better F-statistic, Prob>F and $\mathrm{R}^{2}$. The ROCE model has a better model fitness with Prob>F of 0.011 and R-square of 3.9\%. According to Cohen (1992), $\mathrm{R}^{2}$ is low around 0.1, medium around 0.3 and large around 0.5 . When compared with the $\mathrm{R}^{2}$ of this study, which is $3.9 \%$, it is large.

From the results in Table 8 , introductory stage, growth stage and shakeout stage have no significant effects on financial performance. Thus, hypotheses one, two and four, which state that introductory stage, growth stage and shakeout stage have no significant effects on financial performance are herewith accepted. However, maturity stage shows positive and significant effect on firm financial performance. Thus, hypothesis three, which states that business maturity stage has no significant effect on financial performance is herewith rejected and the alternative hypothesis accepted.

These results when compared and contrasted against previous empirical results can be classified into three. The first group that agrees with the findings of this study are Wahba and Elsayed (2014), Hossain (2014), Gunu and Adamade (2015), Oluwatayo et al. (2016), Zhou et al. (2016), Gulec and Karacaer (2017) and Costa et al. (2017). However, the second group completely disagrees with the findings of this study and they include Chang et al. (2017), Habib and Hassan (2017), Bayat and Noshahr (2018) and Shahzad et al. (2019). Finally, the third group had mix results when compared and contrasted with the findings of this study and the scholars include Khamak et al. (2018) and Chang and Ma (2019). 


\section{Conclusion and Recommendations}

In this study, we empirically interrogate the influences of company life cycle on its financials. Our findings would have implications for stakeholders (managers, regulators, shareholders, creditors, employees, potential investors, governments, tax authorities, policy makers) in implementing measures, strategies and guidelines at the different phases. The findings will assist in order to avoid slipping into the next phase, which is decline or restructuring. The paper will help in policy and performance improvement, future research and body of knowledge. Based on the findings, the study recommends that managers should adopt extra measures to improve performance during the period of maturity in order to avoid their firms entering into shakeout or decline phase.

\section{References}

Andrija, S., \& Filip, S. (2017). A review of the economic value added literature and application. UTMS Journal of Economics, 8(1), 19-27.

Ashbaugh-Skaife, H., Collins, D. W., Kinney Jr., \& LaFond, R. (2009). The effect of SOX internal control deficiencies on firm risk and cost of equity. Journal of Accounting Research, 47(1), 1-43. https://doi.org/10.1111/j.1475-679X.2008.00315.x.

Bayat, A., \& Noshahr, Z. B. (2018). The effect of firm life cycle on corporate performance. Journal of Organizational Behavior Research, 3, 3-17. Doi: Kod/ID: 81S2212.

Chang, H. Y., \& Ma, C. A. (2019). Financial flexibility, managerial efficiency and firm life cycle on firm performance: An empirical analysis of Chinese listed firms. Journal of Advances in Management Research, 16(2), 168-180. https://doi.org/10.1108/JAMR-06-2017-0072.

Cohen, J. (1992). Statistical power analysis. Current Directions in Psychological Science, 1(3), 98-101. https://doi.org/10.1111/1467-8721.ep10768783.

Costa, W. B., Macedo, M. A., \& Almeida, J. E. F. (2017). The determinants of the life cycle stages of Brazilian public companies: A study based on financial accounting variables. Brazilian Business Review, 14(3), 304-320. doi: http://dx.doi.org/10.15728/bbr.2017.14.3.3.

Etale, L. M., \& Otuya, S. (2018). Environmental responsibility reporting and financial performance of quoted oil and gas companies in Nigeria. European Journal of Business and Innovation Research, 6(6), 23-34.

Gujarati, D. (2003). Basic Econometrics (4th ed.). McGraw-Hill.

Gulec, O. F., \& Karacaer, S. (2017). Corporate life cycle methods in emerging markets:

Evidence from Turkey. Journal of Economics, Finance \& Accounting, 4(3), 224-236. doi: 10.17261/Pressacademia.2017.690.

Gunu, U., \& Adamade, S. S. (2015). The relationship between firm age and financial performance in Nigeria: A panel analysis. J. of Sustainable Dev. in Africa, 17(3), 128-141.

Habib, A., \& Hassan, M. M. (2015). Firm life cycle and corporate performance. Journal of Accounting and Finance, 57(2), 465-497. doi: https://doi.org/10.1111/acfi.12141.

Hasan, M. M., \& Hossain, M., \& Cheung, A. Wai-Kong., \& Habib, A. (2015). Corporate life cycle and return on capital employed. Journal of Contemporary Accounting and Economics, 11(1), 46-60. DOI: 10.1016/j.jcae.2014.12.002.

Khamaki, A., Saeidi, P., Naderian, A., \& Khozain, A. (2018). The relationship between capital investment choice and capital productivity: A test of firm life cycle theory. Advances in Mathematical Finance and Applications, 3(4), 83-100. doi: 10.22034/amfa.2018.577349.1124.

Madugba, J. U., \& Ogbonnaya, A. K. (2016). Working capital management and financial performance: Evidence from manufacturing firms in Nigeria. European Journal of Accounting, Auditing and Finance Research, 4(9), 98-106.

Magni, C. A. (2010). Average internal rate of return and investment decisions: A new perspective. The Engineering Economist, 55(006653), 1-14. doi: 10.1080/00137911003791856.

Ogneva, M., Raghunandan, K., Subramanyam, K. (2007). Internal control weakness and cost of 
equity: Evidence from SOX Section 404 disclosures. The Accounting Review, 82, 1255-1297.

Oluwatayo, A. A., Amole, D., \& Uwakonye, O. (2016). Organizational life cycle, business

orientation and performances of architectural firms in Nigeria. Construction Economics and Building, 16(1), 50-63. doi: http://dx.doi.org/10.5130/AJCEB.v16i1.4662.

Patrick, M., \& French, N. (2016). The internal rate of return: Projections, benchmarks and pitfalls. Journal of Property Investment \& Finance, 34(6), 664-669. https://doi.org/10.1108/JPIF-07-2016-0059.

Shahzad, F., Lu, J., \& Fareed, Z. (2019). Does firm life cycle impact corporate risk taking and performance? Journal of Multinational Financial Management, 51, 587-609. doi: 10.1016/j.mulfin.2019.05.001.

Wahba, H., \& Elsayed, K. (2014). The effect of life cycle stage of a firm on the relationship between board size and financial performance. International Journal of Managerial and Financial Accounting, 6(4), 273-295. doi: 10.1504/IJMFA.2014.066399.

Yoo, J., Lee, S., \& Park, S. (2019). The effect of firm life cycle on the relationship between R\&D expenditures and future performance, earnings uncertainty and sustainable growth. Sustainability, 11(2371), 1-19. doi:10.3390/su11082371.

Zhou, H., Chen, H., \& Cheng, Z. (2016). Corporate life cycle and firm performance. In J. Jay Choi , Michael R. Powers, Xiaotian Tina Zhang (ed.). The political economy of Chinese finance. International Finance Review, 17, 189-209. 